\title{
9. 電流駆動・加熱系
}

藤沢 登, 木村晴行, 小原祥裕, 上原和也, 山本 巧

（日本原子力研究所）

(1991年 2 月22日受理)

\author{
Current Drive and Heating System \\ Noboru Fujisawa, Haruyuki Kimura, Yoshihiro Ohara, \\ Kazuya Uehara and Takumi Yamamoto \\ (Received February 22, 1991)
}

\begin{abstract}
ITER current drive and heating system has to provide various functions, such as initial plasma formation, current ramp-up assist, heating to ignition, current drive, current profile control, and burn control. The system is composed of radio-frequency waves with several frequencies and neutral beams with high energy to cover those multi-functions. The first option is based on a neutral beam $(75 \mathrm{MW}, 1.3 \mathrm{MeV})$, lower hybrid waves $(50 \mathrm{MW}, 5 \mathrm{GHz})$ and electron cyclotron waves $(20 \mathrm{MW}, 120 \mathrm{GHz})$. Another candidate uses ion cyclotron waves $(130 \mathrm{MW}, 15-80 \mathrm{MHz})$ instead of the neutral beam. The conceptual designs for those four systems are described here.
\end{abstract}

Keywords :

ITER, conceptual design, current drive, heating, neutral beam system, lower hybrid system, electron cyclotron system, ion cyclotron system,

\section{1. 序 ${ }^{1)}$}

ITER 電流駆動・加熱 $(\mathrm{CD} \& \mathrm{H})$ システムには次の様な機能が必要である。(1)燃料ガスの電離と初期低温 プラズマの生成，(2)非誘導電流立上げ補助，（3）プラズマ自己点火への加熱，(4)韭誘導電流駆動，(5)電流 分布制御，(6)補助加熱による燃焼制御，である。この中で非誘導定常電流駆動の機能が最もパワーを必要

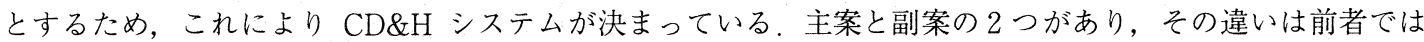
NB を，後者では IC を主電流駆動手段として採用している点である.

主案：中性粒子ビーム系（NBS），低域混成波系（LHS），電子サイクロトロン波系（ECS）

副案：イオンサイクロトロン波系 (ICS), LHS と ECS については主案と同じ.

Naka Fusion Research Establishment, Japan Atomic Energy Research Institute, Ibaraki 311-01. 
ITER では10V 以下のループ電圧で初期プラズマを立上げるために, 数 $10 \mathrm{eV}, 10^{19} \mathrm{~m}^{-3}$ 台の初期プラズマ が必要であり，これを信頼性良く得るために ECS を用いる，局所電流分布制御によるディスラプション制 御も ECS のもj 1 つの大きな役割である. $\mathrm{m}=2, n=1$ テアリングモードを局所的な電流分布制御により安 定化する. EC 波は15〜25の角度を付けてプラズマに打ち込まれる. LHS を電流立上げ補助に用い, ボル トセカンドを節約し，運転領域の拡大を意図している，実験に基づいたモデリングによれば， $<n_{\mathrm{e}}>=2 \times$ $10^{19} \mathrm{~m}^{-3}$ の低密度プラズマでは約 $1 \mathrm{Vs} / \mathrm{MW}$ の結果を得ている.

$\mathrm{CD}$ の主オプションとして NB と LH の組合せを選択しているが, 主な理由はこの組合せが最大の駆動効 率を与えることである。この主オプションではプラズマ内側領域の電流駆動を NB で, 外側領域を LH で カバーする．NB のエネルギーはこの目的に沿うように選択されている，NB 電流駆動については電流駆動の データベース, NB ビームの電離断面積, プラズマの回転等の課題を検討した，LH については如何に電流駆 動効率を上げるか，アルファ粒子との干渉を避けるか等を主な物理課題として検討した．LH の不確定性は 実験を十分に説明できるモデルが確立していないことである.

IC 電流駆動として低周波領域（15 $\mathrm{MHz})$ を採用し，イオンのダイピング を避けて電流駆動効率を上げている。ま た高周波領域 ( $<80 \mathrm{MHz})$ は加熱と燃 焼制御に使用する。IC の課題は電流駆 動についてのデータベースがそしいこと である。

上記 4 システム概念設計の基本的な諸 表1-1. 電流駆動・加熱システム諸元

\begin{tabular}{|c|c|c|c|c|}
\hline & ECS & LHS & NBS & ICS \\
\hline 電流駆動効率 $F O M=n_{20} 1 / R P$ & 0.2 & 0.35 & 0.45 & 0.3 \\
\hline 電流駆動パワー & 20 & 50 & 75 & 130 \\
\hline ソースでのパワー (MW) & 24 & 80 & 150 & 145 \\
\hline 運転電力 (MW) & 80 & 115 & 190 & 240 \\
\hline 効率 (プラズマ入カ/運転電力) & 0.25 & 0.4 & 0.4 & 0.6 \\
\hline 稼働チャネル/ソース & $24 / 1 \mathrm{MW}$ & $100 / 0.8 \mathrm{MW}$ & $9 / 8.3 \mathrm{MW}$ & $42 / 3 \mathrm{MW}$ \\
\hline 周波数/電圧 & $120 \mathrm{GHz}$ & $5 \mathrm{GHz}$ & $1.3 \mathrm{MeV}$ & $15 \sim 80 \mathrm{MHz}$ \\
\hline ランチャー/アンテン数 & 1 & 2 & 無 & 42 \\
\hline ポート数 & 1 & 2 & 3 & 7 \\
\hline 入射角（径方向を基準） & $15 \sim 25^{\circ}$ & 0 & $18^{\circ}$ & 0 \\
\hline
\end{tabular}
元を表1-1に示す.

\section{2. 中性粒子ビーム系 (NBS)}

\subsection{NBS 設計条件}

NBS はプラズマの加熱ばかりでなく，プラズマ内 側領域の電流駆動や電流分布制御という重要な役割 を単一のシステムで果すことが出来るという優れた 特長を持っている. ITER の物理検討及び炉システ ム検討に基づいて，表2-1に示す基本仕様を決めた。 ビームエネルギーは中性粒子ビームのプラズマ中へ の透過㧍よび電流駆動効率を考慮して $1.3 \mathrm{MeV}$ とい う高エネルギービームが必要である。入射パワーは
表2-1. ITER/NBS 基本仕様

\begin{tabular}{l|l}
\hline 中性粒子入射パワー & $75 \mathrm{MW}$ \\
ビーム種 & $\mathrm{D}$ (H も可) \\
ビームエネルギー & $1.3 \mathrm{MeV}$ (最大) \\
パルス幅 & $350 \mathrm{hr}$ (2週間連続) \\
ビーム強度分布 & プラズマ位置で中空, 平坦, \\
& 中心集中分布などに可変 \\
入射パワーステップ & $10 \%$ \\
入射パワー変化率 & $10 \mathrm{MW} / \mathrm{s}$ 以下 \\
エネルギーステップ & $50 \%, 75 \%, 100 \%$ \\
エネルギーステップ変化率 & $10 \mathrm{~s}$ \\
入射方向 & $R=6.2 \mathrm{~m}$ への接線入射 \\
ポート寸法 & $0.8 \mathrm{~m}$ (幅) $\times 3.4 \mathrm{~m}$ (高さ) \\
トリチウム蓄積量 & $10 \mathrm{~g}$ 以下 \\
不純物入射量 & $3.5 \times 10^{16}$ atom $/ \mathrm{s}$ 以下 \\
対向面パワー密度 & $0.6 \mathrm{MW} / \mathrm{m}^{2}$ 以下 \\
\hline
\end{tabular}


非誘導電流駆動によるトカマク定常運転の観点から，またエネルギーや入射パワーのステップおよび变化率 はプラズマの安定制御と燃焼制御の観点から決めた，更に入射ビームの空間分布制御による電流分布制御は プラズマの安定な高ベー夕化にとって重要な機能である。本機能は当初 FER 用に提案されたものである が2),ITER でもその重要性が認められ採用された。

表2-1に示す要求項目に基づいて, 各国間で表2-2に示す NBS の共通設計基準を決めた。 NBS は 3 カ所の 入射ポートを使用し，各ポートには 3 ユニットのビームラインを垂直方向に 3 段配置する。各ビームライン は最大 $1.3 \mathrm{MeV}, 10 \mathrm{MW}$ の中性粒子ビームを入射することができ，1 ユニットが故障しても他のユニットで カバーし，高稼働率を保つ設計とすることとした，本基準に基づいて各国は概念設計を提案したが ${ }^{3)}$ ，統一

\section{表2-2. ITER/NBS 共通設計基準}

\begin{tabular}{l|l}
\hline ポート数 & 3 \\
ビームライン/ポート & 3 \\
入射パワーノビームライン & $10 \mathrm{MW}$ at $1.3 \mathrm{MeV}$ (最大) \\
ビームライン寸法 & 約 $4 \mathrm{~m}$ (直径) $\times 15 \mathrm{~m}$ (長さ) \\
加速器出ロートーラス接線入射点間距離 & $46.5 \mathrm{~m}$ \\
\hline
\end{tabular}

案にはいたっていない.今後の R\&D の結 果を取り込みながら順次統一案の作成を行っ ていく予定である。以下に ITER/NBSの概 要，設計上のオプション及び今後の計画につ いて述べる。

\subsection{NBS の概要}

NBS はイオン源, ビームライン, 電源各 9 ユニット, および各ユニット共通の冷却系，ガス供給系，冷媒 供給系，遠隔保守系等の補機設備よりなる。これらの補機設備は ITER 共通設備と結合され，集中管理制 御される。図2-14) は 9 ユニットのうち1 ユニットの構成を模式的に示したものである。ビームラインの基 本構成は従来の NBS との共通点が多い.しかし, エネルギーが従来より約 1 桁高い $1.3 \mathrm{MeV}$ であるため,

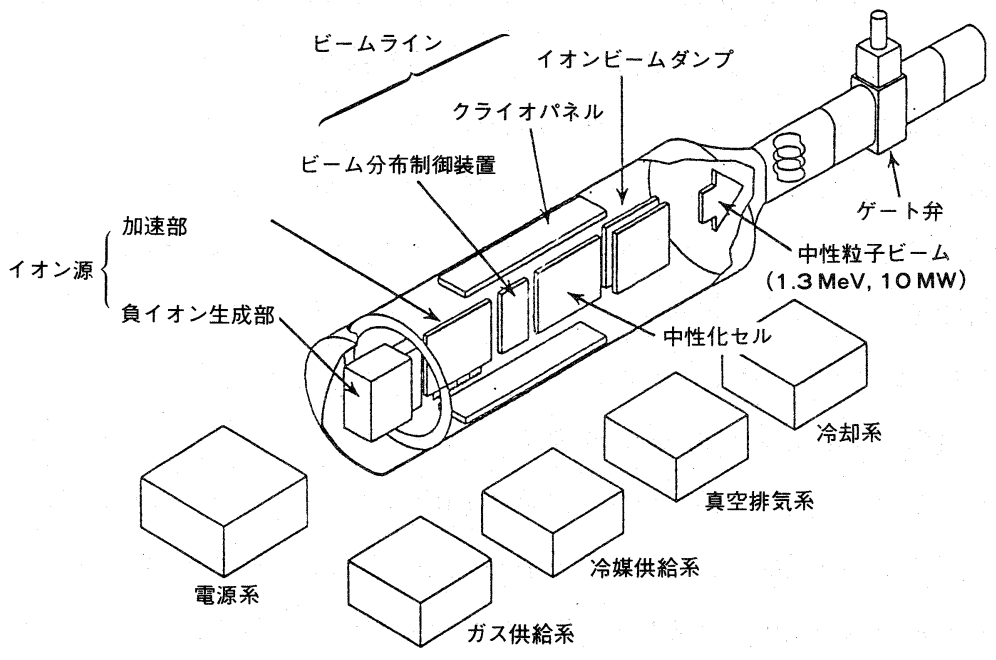

図2-1. ITER/NBS 1 ユニットの模式図(文献 4 より転載) 
核融合研究 第65巻第 4 号 $\quad$ 1991年 4 月

正イオンを用いたのでは中性粒子ビームへの変換効率が極めて低くなるため, 高エネルギー領域でも高い中 性化効率を得ることができる負イオンを用いている。これが従来の NBS と最も異なる点である.

負イオン源は負イオン生成部と加速部より成る. 負イオン生成部において引出された重水素負イオンは加 速部において静電的に加速される. 加速部出口において $1.3 \mathrm{MeV}$ で約 $15 \mathrm{~A}$ の負イオンビームはビーム分布制 御装置に入射され, 磁場又は電場により垂直方向に偏向される ${ }^{3)}$. 偏向制御された負イオンビームは中性化 セルに入射され，その一部はガスとの衝突により中性化されて直進し，入射ポートを通してプラズマに入射 される，プラズマ位置でのビーム入射位置を中心部から周辺部に変えることによりプラズマ電流分布の制御 を行う，負イオンのうち $60 \%$ は中性化されるが，残り40\%の半分は正イオンとなり半分は負イオンのままで ある。これらの残留イオンは磁場又は電場により偏向分離され, 中性化セル出口部に配置されているビーム ダンプに衝突させて熱化処理する. ビームラインは長いドリフト管でトカマクの真空容器に接続されるが, 間には 2 重ゲート弁が設置され, 保守時に真空的に切り放すことができる. 又ビームライン内には定常運転 に対応した大容量クライオポンプが配置されており, イオン源拉よび中性化セルに導入されるガスを排気す る. 真空排気系は本体の燃料供給処理系と結合されており, 排気されたガスは精製されて再びイオン源や中 性化セルに供給される。

電源はイオン源用電源及びビームライン用電源より成る. 特にイオン源用電源の中で $1.3 \mathrm{MV}$ の加速電源が 技術的にもっとも難しいものである，加速部内で生じる電気的な絶縁破壊にたいして，イオン源電極の保護 ばかりでなく, 電源自身の保護のために高速遮断機能が要求される. しかし, 従来の直流高圧側での高速遮 断は電圧が1.3MV と高いため技術的に難しい.このため $500 \mathrm{~Hz}$ - 数 $\mathrm{kHz}$ の高周波インバータを用いて, 交 流低圧側で高速遮断する方式 ${ }^{5)}$ を採用している。

ビームラインの中性子遮蔽設計は炉対応の設計とする上で極めて重要な項目である．入射ポート第一壁部 より約 $28 \mathrm{~m}$ 離れたビームライン取付け部における中性子束は7.7 $\times 10^{10} \mathrm{n} / \mathrm{cm}^{2} \cdot \mathrm{s}$ (total), $2.2 \times 10^{10} \mathrm{n} / \mathrm{cm}^{2}$ ・ $\mathrm{s}(14 \mathrm{MeV})$ である ${ }^{6)}$. 必要な入射ポート開口部寸法はイオン源の性能やビームラインの設計によっても大き な影響を受けるが, 最大 $10^{14} \mathrm{n} / \mathrm{s}$ のオーダーの中性子が各ビームライン内に流入する。この中性子をビーム ライン容器壁で生体遮蔽することは可能であるが, その重量が巨大となり, 建屋構造ばかりか遠隔保守シナ リオにも影響を与える。一方ビームラインの軽量化を計れば, 室内空気や室壁の放射化は免れず, 大量の低 レベル放射化物を生成することとなる，現状ではビームライン室内は不活性ガスに置換すると共に，室壁に は $\mathrm{B}_{4} \mathrm{C}$ などの中性子吸収材を張り付けることによりビームラインの軽量化を図っている.

一方, ビームライン機器の遠隔保守は現場での修理保守が難しい. ビームラインを解体すれば周囲はたち まち高レベルの誘導放射能に晒されるばかりでなく, 放射化物のビームライン外への漏洩も来たすため, 人 や機械が現場で解体保守することは難しい.このためイオン源やビームラインは 2 重のドアシステムのゲー ト弁で分離し, 内部の放射化物が室内に漏洩しないようにビームライン室外のホットセルに持ち込み保守修 理を行う. 


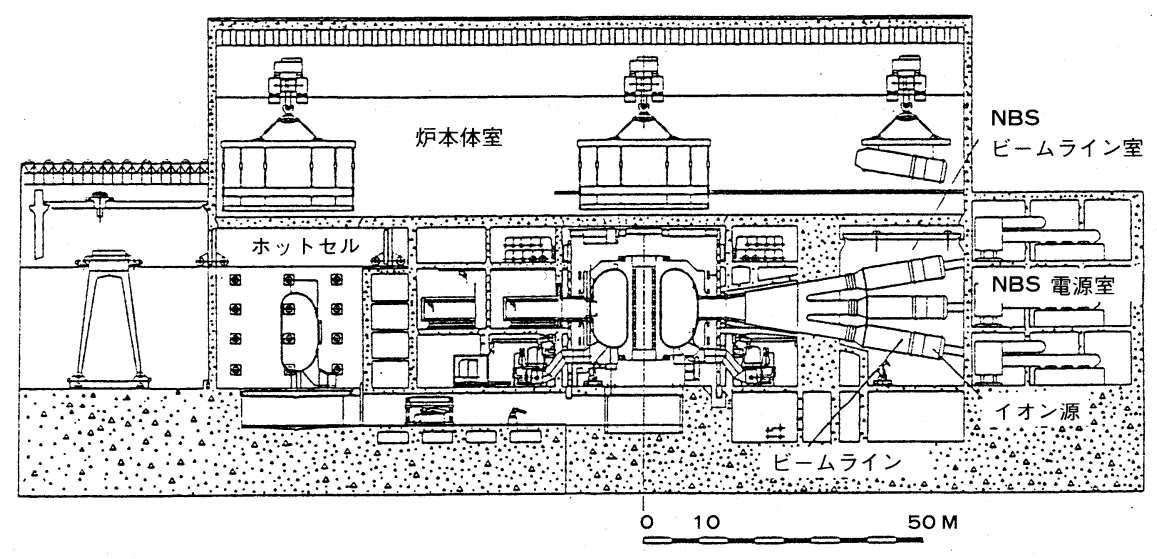

図2-2. ITER 炉本体断面と NBS

3 ユニットのビームラインを炉本体に取付けた断面図を図2-2に示す，又，NBS の効率は約40\%と見積っ ている.内訳は加速効率：90\%, 中性化効率：60\%, 幾何学的損失：5\%, 再電離損失： $5 \%$, 電源効率及 びその他：82\%である，今後の R\&Dによりプラズマ中性化セルが開発できれば総合効率を更に改善できる．

\section{3 設計オプション}

NBI の設計はポート部や建屋構造を除き他システムの設計との干渉は少ないので，1つの設計案に統一す る作業はまだ行っておらず，多くの設計上のオプションを残している，これらのオプションは R\&D の結果 を見て選択していく．以下にオプション項目として特に重要なものについて述べる．

(1) イオン源の電位

イオン源の負イオン生成部を接地電位にし, 中性化セルに正の高電位を与えて負イオンを加速するイオン 源接地方式か, 又は逆にプラズマ生成部に負の高電位を印加して負イオンを加速する中性化セル接地方式か で，ビームライン構造や電源の設計は大きく変る、いずれの方式を採用するかはイオン源を安定に運転する 上で必要なサージ抑制を有効にできるか否かの R\&D にかかっている.

(2) 負イオン生成方式

体積生成方式，表面生成方式，両方式の混合型な ている，如何に低い運転ガス圧で高い負イオン生成密度を安定に得られるか, 又加速系との整合性は良いか が重点な点である，今後イオン源を定常化するため高周波放電の利用も考えており，更に改良されていくも のと思われる。

(3) 負イオン加速方式

負イオンの加速方式として高加速効率と高電源効率を得られる点で, 静電的な加速方式を採用している. 静電加速でも多孔-多孔型静電加速方式 (ES), 多孔-単孔型静電加速方式 (ES), 静電四重極加速方式 
核融合研究 第65巻第 4 号 1991年 4 月

$(\mathrm{ESQ})$, 等が提案されている. $\mathrm{ESQ}$ 方式の電源は多くの中間電位出力を制御する必要があり, 電源の設計上 難しさが予想される. ES 方式でも従来の $\mathrm{mA}$ 級加速管と同じ構造で加速することは考えておらず, 加速過 程で生じる電子の高エネルギーへの加速の抑制を各加速電極に埋め込まれた磁石の作る磁場で行うことを考 えている，どうような加速方式がビーム光学上，耐電圧上最も信頼性があるかは今後の緊急を要する R\&D 項目である。

(4) 中性化方式

中性化セルとして重水素のガスセルを用いても，60\%と言う高い中性化効率を得ることができるのでシス テム設計上支障はない. しかしプラズマ中性化セルを開発できれば，80\%以上の高い中性化効率を得ること ができる。しかも中性子セルやビームダンプの小型化, クライオポンプ容量や電源容量の低減, 更にビーム ライン本数を少なくできるなどの大きな効果を期待できる。このためには十分小さいパワーで如何に高い電 離度のプラズマを生成できるかにかかっており，今後の重要な R\&D 項目の 1 つである.

\subsection{R\&D の現状と計画}

ITER/NBS を実現する上で最も重要な機器が $1.3 \mathrm{MeV}, 15 \mathrm{~A}$ 級の重水素負イオン源である. 負イオンの生成 に関しては近年大きく進展し, 負イオン電流及び電流密度ともすでに ITER の設計值に手が届く領域まで達 している7). 負イオンの $1.3 \mathrm{MeV}$ への加速に関しては $\mathrm{mA} レ$ レ゙の加速であれば, 既存の技術の範囲内であ るが, 従来よりも約 3 桁も高い電流を $\mathrm{MeV}$ 領域まで安定に加速できるか否かは大きな課題である。このた め今後 4 力国共同で加速の原理実験を行うと共に, 国際大型試験施設を建設して $1.3 \mathrm{MeV}, 5 \mathrm{~A}$ の負イオン ビーム生成の実証試験を計画している，各国の負イオン源開発の現状と目標值を図2-3に示す。更に，設計 オプションを決める上で必要なプラズマ中性 化セルなどの要素開発も並行して行い，97年 頃までに建設への技術的見通しが得られるよ うに，各国協力して研究開発を進める予定で ある。

\section{3. 低域混成波系 (LHS)}

\subsection{ITER/LH の物理要請と仕様}

$\mathrm{ITER} / \mathrm{LH}$ の物理要請は電流立上げ補助 及び周辺電流駆動である。概念設計活動 (CDA)で合意に達している設計仕様を表3-1 に示す.システムの周波数は $5 \mathrm{GHz}$ で, これ はアルファ粒子によるパワー吸収を避けるこ

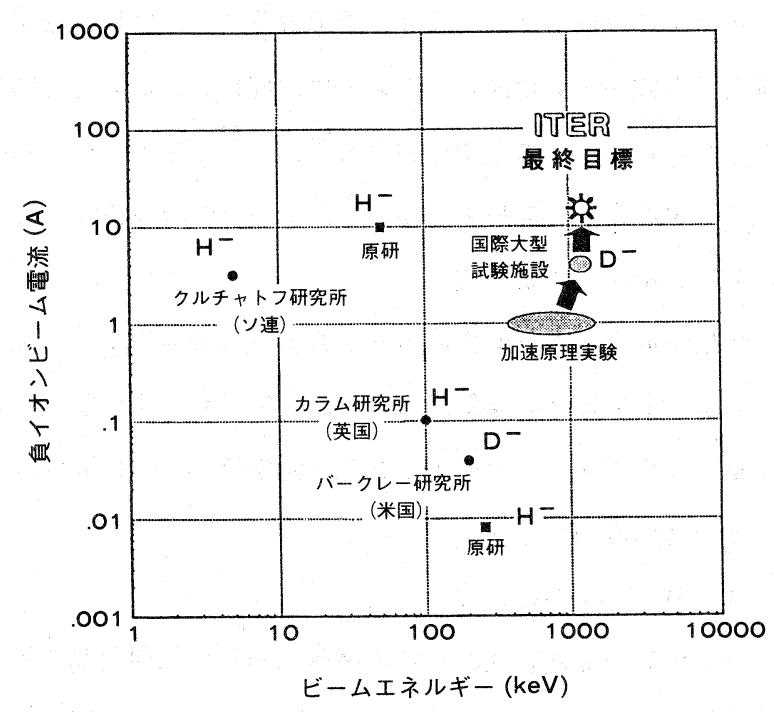

図2-3.世界における負イオン源開発の現状と今後の計画 
とも考慮されている。これょりも高い周波数の方が波の吸収がよいという計算もあるが，周波数が余り高く なると, システムの総合効率が $\mathrm{RF}$ 損失の増大により増えるので, 余り周波数を高くできない. またこの周 波数帯の電子管は技術的にも開発が可能なものであり現実的である. 2 つのポートを用いて赤道面のやや下 の領域に水平ランチャーを設置するが，これはレイトレーシングによる波の伝播とカップリングの良さが考 虑されている. 45-50MW の RF パワーを単管0.7-0.8MW の電子管で供給するには約100本のクライストロン が必要である。ランチャーはマルチジャンクション型を使用し, 電流駆動の効率を上げるために放射スペク トルはできるだけシャープに且つ方向性の良いものを選定している。

表3-2. LH ランチャー仕様

表3-1. ITER/LHS 主要諸元

\begin{tabular}{|c|c|}
\hline 周波数 & $5 \mathrm{GHz}$ \\
\hline 入射電力 & $45-50 \mathrm{MW}$ \\
\hline ポート数 & 2 (下半分) \\
\hline 高周波源 & クライストロン \\
\hline 単管出力 & $0.7-0.8 \mathrm{MW}$ \\
\hline 効率 & $0.6-0.7$ \\
\hline 本 数 & 約100本 \\
\hline 伝 送 系 & WR-229, WR-650 \\
\hline 結 合系 & マルチジャンクション \\
\hline $\begin{array}{l}\text { 屈 折 率 } \\
\text { 放射スペクトル }\end{array}$ & $1.3-1.8$ \\
\hline の半值幅 & 0.15 \\
\hline
\end{tabular}

\begin{tabular}{|c|c|}
\hline \multicolumn{2}{|l|}{ 導波管 } \\
\hline モジュール数 & $N_{\text {toroidal }} \times M_{\text {poloidal }}$ \\
\hline $\begin{array}{l}\text { 個数 (1 モジュール当たり) } \\
\text { 基本導波管寸法 }\end{array}$ & $\begin{array}{l}n_{\text {toroidal }} \times m_{\text {poloidal }} \\
\text { 高さ }=50 \mathrm{~mm}, \text { 横幅 }=4.5 \mathrm{~mm}, \\
\text { 厚さ }=1.5 \mathrm{~mm}\end{array}$ \\
\hline 固定位相差 & $60^{\circ}$ \\
\hline 伝送パワー密度 & $5.0 \mathrm{~kW} / \mathrm{cm}^{2}$ \\
\hline 導波管先端材質 & $\mathrm{Be}$ \\
\hline ガードリミター材質 & $\mathrm{C}$ \\
\hline 導波管材質 ～～～ & グリッドコップ \\
\hline モジュール間絶縁 & 無し \\
\hline \multicolumn{2}{|l|}{ 導波管温度 } \\
\hline 運転中 & $150^{\circ} \mathrm{C}$ 以下 ベーキング中 $250^{\circ} \mathrm{C}$ \\
\hline 遒波管内圧力 & $10^{-5}$ Torr 以下 \\
\hline ガス放出量 & $10^{-7}$ Torr $\cdot 1 / \mathrm{s} \cdot \mathrm{cm}^{2}$ \\
\hline 中性子線量（空） & $10^{18} \mathrm{n} / \mathrm{cm}^{2}$ \\
\hline
\end{tabular}

\section{2 ランチャー}

\section{(1) 構造}

LH ランチャーの仕様を表3-2に示す，ランチャーの基本的要素はマルチジャンクションモジュールである. 1 つのモジュールは導波管がトロイダル方向に $n$ 分割, ポロイダル方向に $m$ 分割され, 合計 $n \times m$ 個の導 波管アレイを構成する（ITER 設計值では $n=4$ 又は $6, m=4$ 又は 2 である）。この導波管アレイモジュー ルは更にトロイダル方向に $N$ 個ポロイダル方向に $M$ 個接合されて, $N \times M$ 個のモジュールで構成されるマル チジャンクションランチャーとなる，トロイダル方向の1列の導波管個数は, ITER では $n \times N \sim 100$ 個を想 定している，60\%の位相差は基本導波管の固定位相を示すもので，この角度は放射スペクトルの方向性が良 い，伝送密度の值は現在得られている大型装置での実績値から考えて妥当なものである，導波管材質につい ては後でも述べるが，熱的及び機械的設計から充分耐えられるやアルミナ分散銅（グリドコップ，G-C）と し，再先端はエロージョン対策を考慮してベリリウムを選んでいる．電流駆動時のリミターへのホットス ポット対策としてランチャーの前面はカーボンリミターを取り付けている．モジュール間の絶縁の必要性も 後で述べるがディスラプション回避の設計に依存している，効果的なランチャーエーシングを達成するため に，導波管のベーキングや導波管内の真空排気を計画している。この時の導波管の温度と圧力は 2 つのオプ 
ションがある，この違いは RF 印加中の導波管内でのガス放出量の評価の違いからきている，1 つは JT-60 の LH 実験での実績から $10^{-8} \mathrm{Torr} \cdot l / \mathrm{s} \cdot \mathrm{cm}^{2}$ に基づいたものであり，1つは Tore-Supra で観測した実績 を基にこれょりも 2 桁大きなガス放出を想定するものである ${ }^{8)}$.この場合は，使用するポンプが非常に大規 模なものが必要である，CDA ではこの中間の $10^{-7} \mathrm{Torr} \cdot l / \mathrm{s} \cdot \mathrm{cm}^{2}$ を採用している．空の位置はクライオス タットの中を想定しているが, 中性子線量が許容值以下になるまで導波管を曲げる等の遮蔽が必要である. 図3-1に RF ポート付近の LH ランチャーの鳥㒈図を示す.

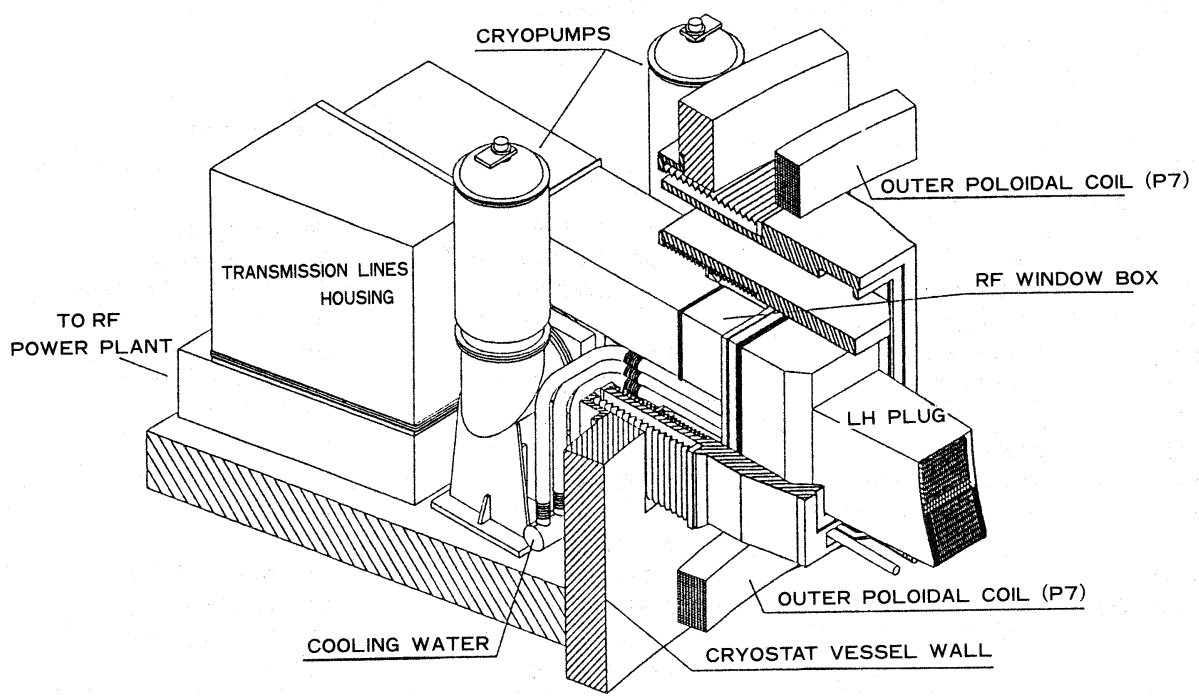

図3-1. ITER/LH ランチャー鳥瞰図
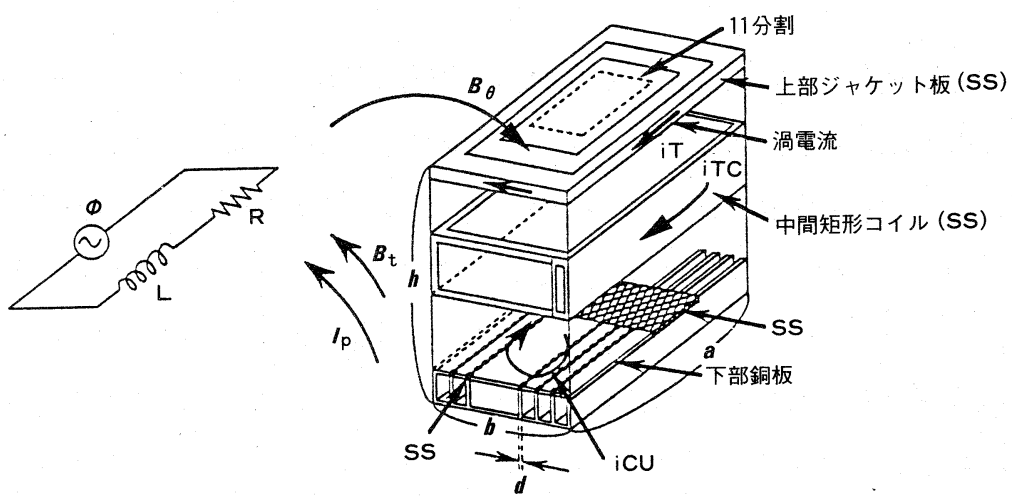

図3-2、ディスラプション解析模式図

(2) ディスラプション時の応力解析

ディスラプション時ランチャーにかかる電磁力を等価回路を使った簡単なモデルで評価した. ランチャー は図3-2に示すように上部ジャケット板と中間矩形コイル及び下部銅板で構成されるものとする，各々の部 
分は有限の抵抗Rとインダクタンス Lを持つので，プラズマ電流（22MA）がディスラプションにより急激に 崩壊（22ms）するとランチャーの各部分に図に示すような渦電流が誘起される，計算を簡単にするため，上 部ジャケット板は同心円状に11分割されたコンポーネントの和で近似し，中間矩形コイルは立体の箱で近似 している，下部銅板は図3-2に示すように渦電流を減すために高抵抗のステンレススチール（SS）の仕切り 板を挿入しており，奥の方は SS のカバーがある。電磁力による全体の㨝れ応力は $5.8 \mathrm{kgf} / \mathrm{mm}^{2}$ となり許容 応力 $\left(=11.4 \mathrm{kgf} / \mathrm{mm}^{2}\right)$ により小さい。このようにディスラプション時の応力回避のために導波管内に絶縁 体を挟む必要はない，但し等価的なランチャーの大きさは図3-2に示すようにトロイダル方向の長さを $b=$ $1140 \mathrm{~mm}$, 奥行きを $a=840 \mathrm{~mm}$, 高さを $h=2080 \mathrm{~mm}$, 導波管の厚さ（Septum）を $d=50 \mathrm{~mm}$ としている.

（3）ランチャーの定常熱解析

ランチャーの先端が10mm だけベリリウムで䤭 づけされているという条件の下に，プラズマ運転 中の定常的な熱解析を行った。導波管グリルは SS316で先端管板部がベリリウムの䤻づけがなさ れている。ブロックスペイサー及び仕切り板 （Septum）はアルミナ分散銅（G-C) で構成され る。熱応力解析の計算条件を表3-3に示す。計算 結果を表3-4に示したが，結果はいずれのコンポー ネントも許容応力 $\sigma_{0.2 \%}\left(32.8 \mathrm{kgf} / \mathrm{mm}^{2}(\mathrm{SS})\right.$, $\left.14.8 \mathrm{kgf} / \mathrm{mm}^{2}(\mathrm{G}-\mathrm{C}), 21.6 \mathrm{kgf} / \mathrm{mm}^{2}(\mathrm{Be})\right)$ を下 回りメインの銅波管 SS 部扔ける熱応力によ る変位及び温度上昇も問題はない。但しディスラ プション時のような非定常熱解析は今後の課題で ある。

（4）ランチャーの保守

ITER ではランチャーをできるだけコンパクトにして全体を定期的に交換する保守方式と日本の提案した ランチャー先端部のみを真空容器内部で交換する保守方式とがある．交換する先端部は 4 つの部分に分割さ

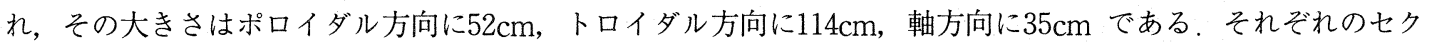
ションの重さは 1 トン以下で，これはトーラスの第一壁に設置する遠隔操作のビークル（車）の操作処理能 力を考慮してのことである。この保守を実現するにはランチャ一前面まで来ている冷却水のパイプの切断と 熔接及びマルチジャンクションの導波管の電気的接触を遠隔操作で実現するための技術を確立する必要があ る、第一壁の保守に用いるレーザーによる熔接と切断の R\&D は1989年日本でなされた ${ }^{9)}$ 。この技術はこの 設計のような比較的径の小さなパイプ（直径約 $5 \mathrm{~cm}$ ）にも適用が可能である. 


\section{3 伝送系とシステムレイアウト}

伝送系の構成は図3-3に示すように, 共通の発振器で52本のクライストロンを駆動する．1つのクライス トロンがトロイダル方向 6 個, ポロイダル方向 8 個の導波管に RF パワーを供給する. 図3-4はクライスト ロンが設置されている部屋から本体室にかけての平面図である。伝送系の長さは約 $50 \mathrm{~m}$ である，それぞれの コンポーネントでのパワーの効率は表3-5に示すように評価される. ランチャーでの入射パワーのクライス トロンから見た効率は76\%で，放射スペクトルの方向性を加味して電流駆動用のパワーとしての効率を評価 すると57-63\%となる。電源を含めたシステムの総合効率はランチャーでの入射パワーでは43-50\%, 電流駆 動用パワーとしては $33-42 \%$ となる。

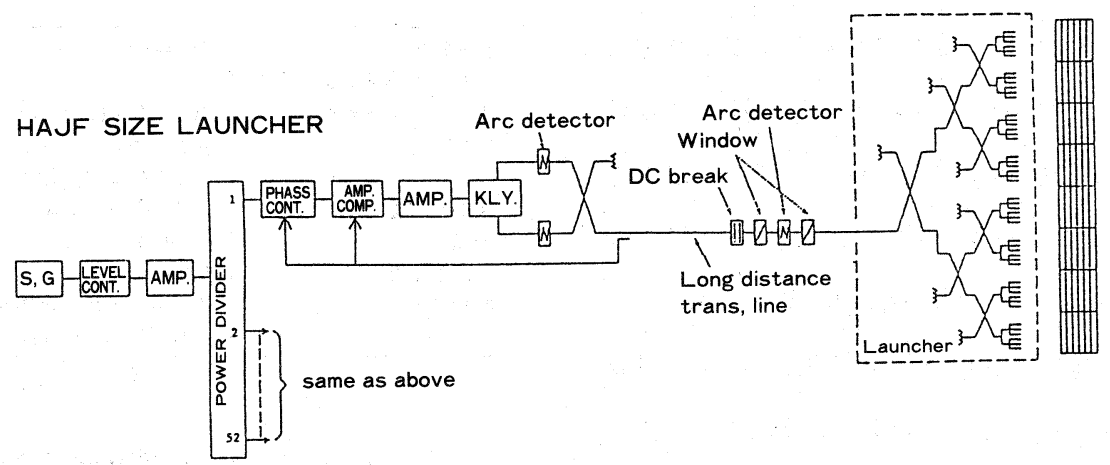

図3-3. 伝送系ラインアップ

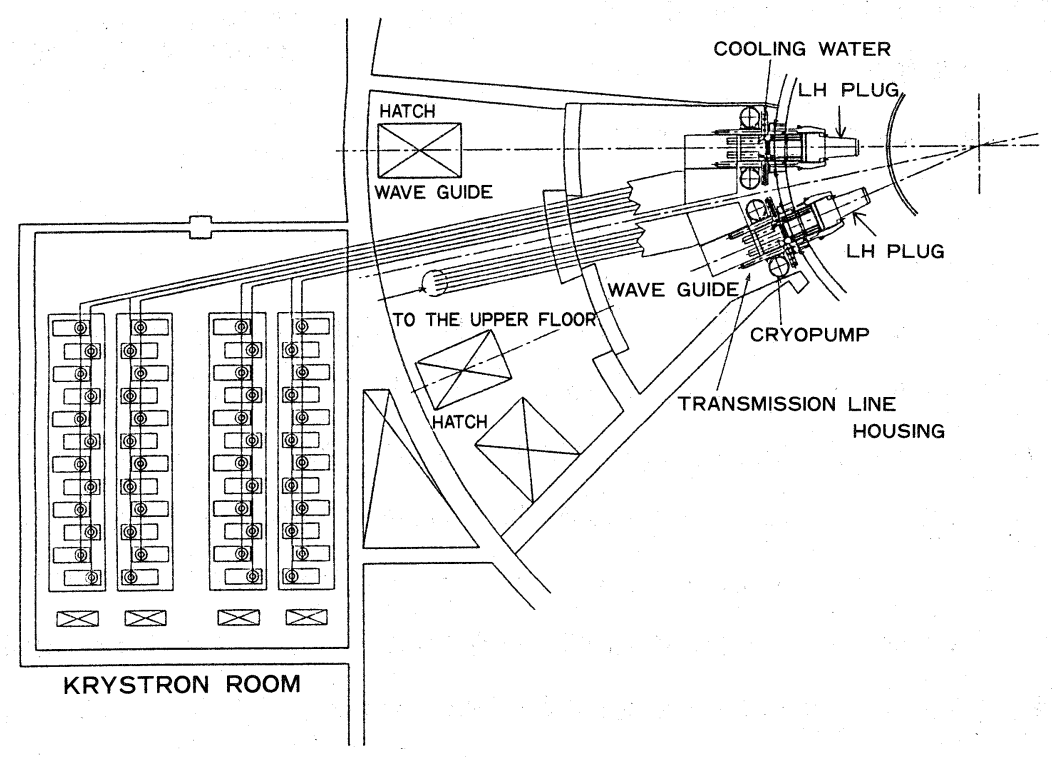

図3-4. ITER/LHS レイアウト (平面図，クライストロン室と本体室) 
表3-5. LHS 総合効率

\begin{tabular}{l|l}
\hline 電源 & 0.95 \\
クライストロン & $0.6-0.7$ \\
ランチャー & \\
マルチジャンクション部 & 0.95 \\
空 & 0.99 \\
透過率 & 0.95 \\
方向性 & $0.76-0.83$ \\
システム総合効率 & \\
入射効率 (クライストロンより) & 0.76 \\
電流駆動 (クライストロンより) & $0.57-0.63$ \\
入射効率 (電源より) & $0.43-0.50$ \\
電流駆動 (電源より) & $0.33-0.42$ \\
\hline
\end{tabular}

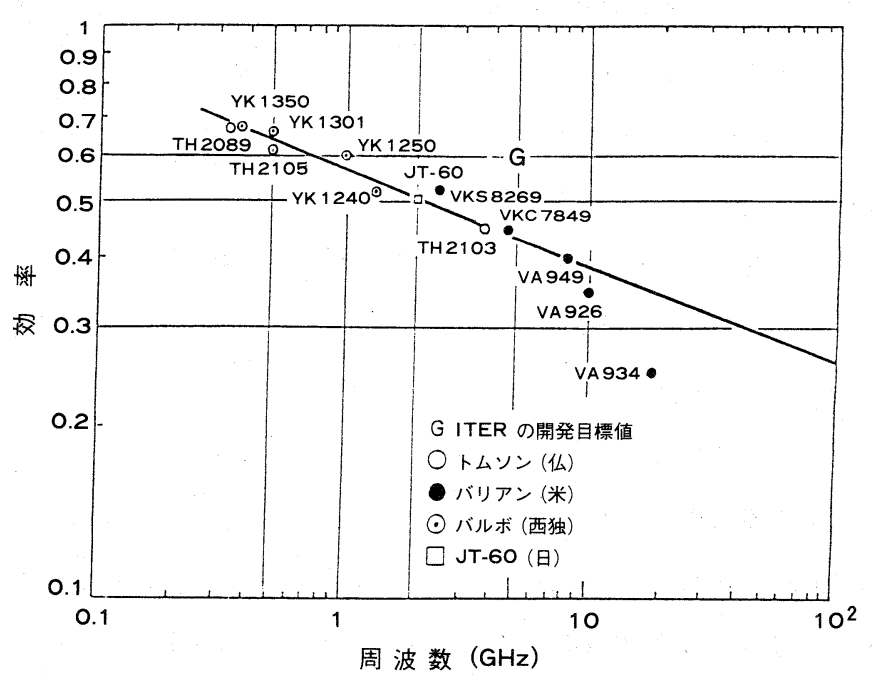

図3-5。世界のクライストロンの開発状況

\section{4 クライストロン}

$\mathrm{LH}$ システムにおける大電力增幅系は周波数 $5 \mathrm{GHz}$, 出力 $0.7-0.8 \mathrm{MW}$ 以上, 効率 $60-70 \%$ のクライストロンの 使用を計画している．今までのクライストロンの開発状況を示したのが図3-5である，効率は周波数の上昇 と共に減少しているのがわかる。これば高周波による熱損失が周波数の2.5乗に比例して増えるので，キャ ビティやコレクターでの熱損失を回避する技術が確立していないことが大きな原因の 1 つである，効率が上 らなければ出力パワーもそれほど上らない. ITER で目標としている領域を Gで示したが上記のクライスト ロンを得るには新たな $R \& D$ が必要である，R\&D が必要な項目は，例えば低パービアンス化による出力上 昇の可能性, 温度上昇とギャップ電界を押さえるためのキャビティの形状の最適化（例えばギャップエッジ を広くテーパー型にする), 更に RF 出力後の電子エネルギーの回収を狙った Depressed Collector による 高効率化への可能性等が揚げられる．周波数が高くなってくると，ジュイロトロンやジャイロクライストロ ンといった電子管との取り合いも考慮してょいであろう，実際イタリアの FTU トカマクでは8GHz の LH シ ステムにジャイロトロンを使用しているし ${ }^{10)}$ ，これらの電子管は位相の制御性の良さや高効率という点で 開発途上にある ${ }^{11)}$.

\section{4. 電子サイクロトロン波系 (ECS)}

\section{1 設計仕様}

$\mathrm{EC}$ 波は効率良く局所的にプラズマを加熱出来ることから，初期低温プラズマの生成，予備プラズマ加熱， 局所電流分布制御などの機能を果たす．ITER の基本仕様ではプラズマ放電の初期誘導電界を $0.3 \mathrm{~V} / \mathrm{m}$ 以下に 設定している，EC 波による初期プラズマ生成によって，低い周回電圧で信頼性良く確実にプラズマ電流を 


\section{核融合研究 第65巻第 4 号 1991年 4 月}

立ち上げることが仕様条件となる．

表4-1. ITER/ECS 設計仕様

又ディスラプションを回避するため

に, $\mathrm{EC}$ 波によって安全係数 $q_{\Psi}=$

2 の磁気面を局所的に非誘導電流駆

動して, 電流分布を MHD 的に安定

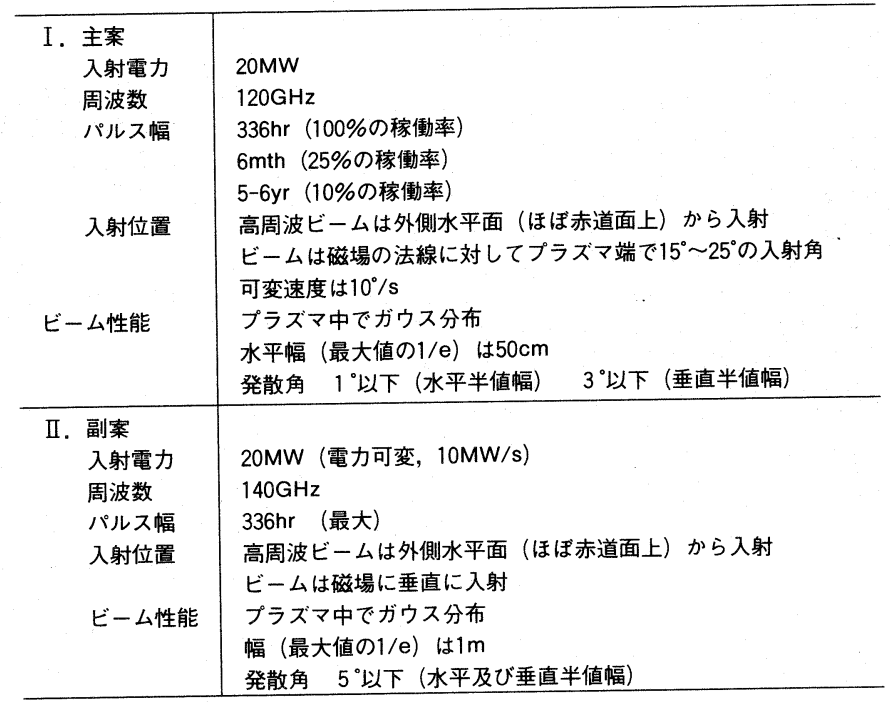

化する. $q_{\Psi}=2$ の磁気面は半径 $\Psi$ $=0.65-0.8$ の領域になることが予測 され，この領域での局所的電流分布 の繊細な制御が必要である。これら は ECS の主案の主な機能である。 一方, ECS の副案の機能として, 追 加熱及び燃焼制御のためのプラズマ 発散角 $5^{\circ}$ 以下 (水平及び垂直半値幅)

中心加熱を検討した．物理要求（主

及び副案）と実現可能な工学条件を考慮して，設計仕様を決定した，その結果を表4-1に要約する.

\section{2 高周波部の基本構成}

図4-1に高周波部の基本構成の鳥瞰図を示す，以下に主案における主要構成部の仕様と性能を示す．主お よび副案に扔ける基本構成では本質的に差はない.

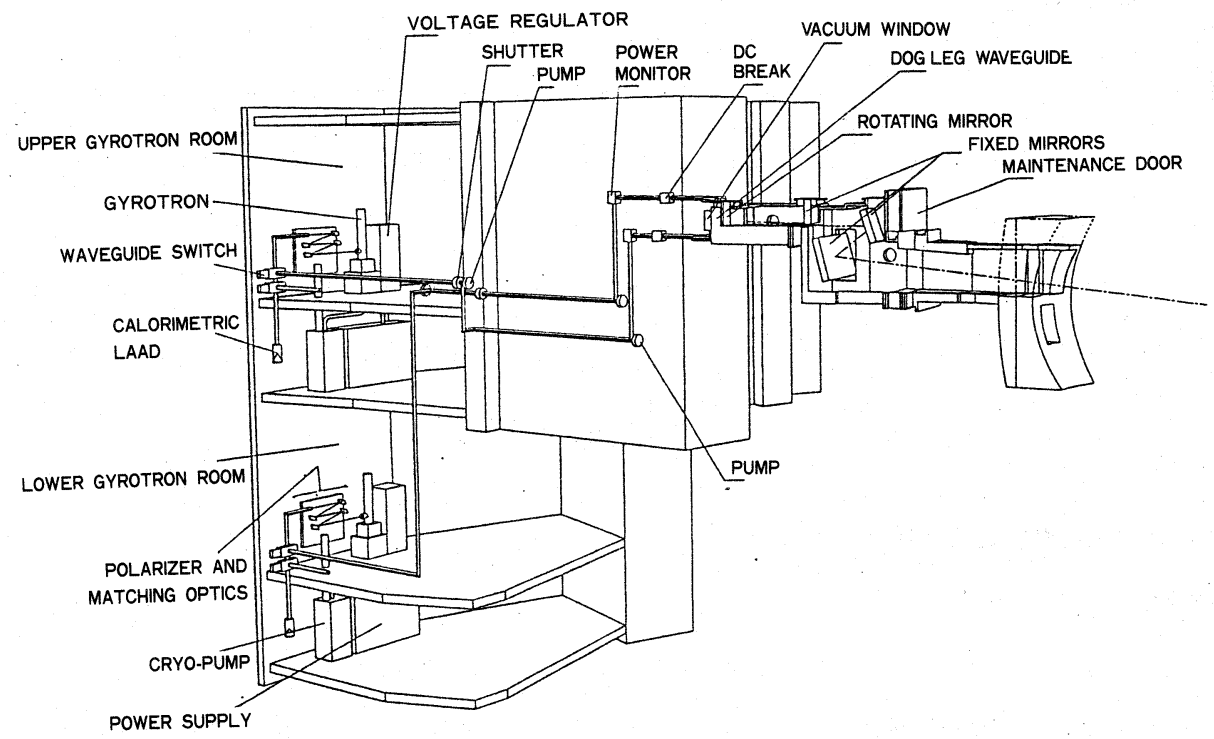

図4-1. ITER/ECS の鳥瞰図 


\section{(1) 高周波源}

高周波源として1MW 連続運転可能なジャイロトロン発振管を28本使用する。 その内24本は常時運動に使用 し，プラズマ中への入射電力を $20 \mathrm{MW}$ とする，即ち伝送系の損失は $4 \mathrm{MW}$ とした．残りの 4 本は予備および保 守・修理のために使用し，100\%の稼働率を期待する. ジャイロトロンからの出力モードはコルゲート導波 管の $\mathrm{HE}_{11}$ モードと良く結合するガウス分布放射モード（ $\mathrm{TEM}_{00}$ モード）とする。ジャイロトロン内に設置さ れたモード変換器を含めての発振効率は30〜50\%とした。 1 本のジャイロトロンは〜 3MW，80-100kV 直流 出力の高安定電源によって駆動される. 高圧電源はジャイロトロンの部屋から隔離された部屋（付帯設備 室）に設置される。又付帯設備室にはジャイロトロンを駆動するために必要な水冷却装置, 超伝導コイル及 びジャイロトロン空冷却用のクライオ装置，伝送系の導波管の排気設備及び高周波模擬負荷を設置する.

\section{(2) 伝送系}

伝送系では主にオーバーサイズのコルゲート円形導波管を使用し, 高耐電力化及び放射性物質の污染除去 のために， $10^{-5} \sim 10^{-2}$ 気圧に導波管内を排気する，伝送モードは低損失モードの $\mathrm{HE}_{11}$ である．ジャイロト ロン出力と円形導波管モードとの結合を効率良くするためにビーム整合ミラー及び光学的フィルターが必要 である，又プラズマ中を斜伝播する EC 波を励起するために楕円偏波器を設置する，その他，伝送系では高 速シャッター, 導波管切替え器, 排気用導波管, ベンド, 電気絶縁導波管, 入射・反射モニタ一用導波管等 を用いる，伝送系及び以下に述べる空とアンテナを含んだ全伝送効率は約 $85 \%$ を設計目標とした。

(3) 高周波空

伝送系にトカマクからのトリチウム及び放射性物質の流入を遮蔽するために, 高周波空を伝送系とアンテ ナとの間に設ける， $\mathrm{HE}_{11}$ モードで動作するクライオ温度に冷却されたサファイア空を採用した．28個の空は 保守・修理の観点から一体化した, 又中性子の放射量が $10^{16} \mathrm{n} / \mathrm{cm}^{2}$ の条件下でも, 高周波空の性能が悪化し ないことを設計条件としている.

(4) アンテナ12)

アンテナは表4-1の設計仕様（ビームの掃引範囲, ビームの大きさ及び発散角）を満足し, かつ信頼性良 く炉環境に耐える構造が必要である. $4 \times 7$ 個に配列されたコルゲート導波管から放射されたビームは, 光 学システムを使用して, 仕様を満足する一束のビームにまとめられ, プラズマ中に入射される. 光学システ ムでは 4 段のミラーを使用する. 初段のミラーは 4 つの局面反射板から成り, 次段の回転ミラー上にビーム を収束する，回転ミラーはビームの入射角を可変にし，加熱領域を制御する．3 番目のミラーは終段ミラー 面上に各ビーム束を重ねる。終段は楕円面を有した反射板で, 最終的な仕様性能を満足するビームを成形す る。これらの 4 個のミラーと他のアンテナ部品（ミラー支持及び冷却機構, 遮蔽バルブ, 診断装置等）はス テンレス製の分離可能な遮蔽ボックス内に取付けられ, アンテナ全体はモジュール化され, 保守・修理を容 易にする構造とした，又光学系では高周波空での中性子量を所定の值以下にするためにクランク構造とし， ビームの光路の断面積をなるべく小さくする設計とした. 
表4-2. ECS 効率

\begin{tabular}{l|c|c|c}
\hline & 現 $\quad$ 在 & 最小の期待値 & 最大の期待值 \\
\hline 電源効率 & 0.9 & 0.9 & 0.95 \\
発振効率 & $0.3-0.35$ & $0.3-0.35$ & 0.5 \\
伝送効率 & $0.75-0.85$ & 0.85 & 0.85 \\
全システム効率 & 0.25 & 0.27 & 0.4 \\
\hline
\end{tabular}

\section{3 主要構成部品の配置と全システム効率}

高周波源が設置してある部屋はトーラス中 心からの距離を $40 \mathrm{~m}$ 以上とし, トカマクが運 転中でも人が入れる遮蔽構造とした。伝送距 離は平均として $45 \mathrm{~m}$ となる。アンテナが設置

されている部屋では保守・修理のためのアンテナモジュールへの近接性を良くする構造とした．システム効 率を表4-2に要約した。最小の期待値は1995年までには実現性の高い值であり, 最大の期待值はその後の開 発目標である。

\section{4 各構成部品の開発課題}

全システム効率を $27 \%$ から $40 \%$ に改善するための主な開発課題はジャイロトロンの発振効率の改善であ る. $30 \%$ から $50 \%$ の発振効率の改善は電子ビーム性能の改善及び電子ビームエネルギー回收装置を採用する ことによって期待できる。電源効率はパワートランジスターをモジュール化した DC-DC 変換器の採用によ り，95\%になることが技術的に予測される ${ }^{13)}$ ，又高速周波数可変ジャイロトロンが開発されれば，アンテ ナ寸法を小さくし，EC システムの融通性を増すことになる. 又1 MW 連続運転可能な高周波空（ジャイロト ロン用及びトカマク用）は主要な開発課題の 1 つである.

\section{5. イオンサイクロトロン波系 (ICS)}

\section{1 はじめに}

イオンサイクロトロン周波数帯（ICRF）波による加熱の実験は大電力の大型トカマクでの実験（JET では 最近 $22 \mathrm{MW}$ の入射を達成した）を中心にして最近特に進歩が著しい. 主な成果として高エネルギーイオンの

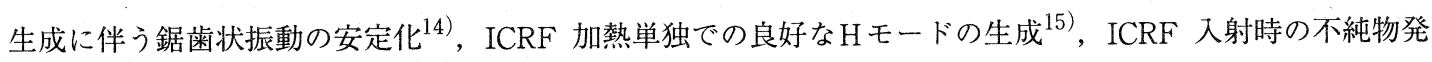
生機構の解明 ${ }^{16,17)}$ 等が挙げられる。またアンテナ，伝送系，高周波増幅器等の技術も基本的に確立してお り ITER のための大規模な技術開発は不要である。このような点から ITER の加熱手段としては相応してシ ステムと言える。一方，電流駆動に関する実験デー夕は現時点では NB よりそしい，また計算コードによる 電流駆動効率の予測值も NB より約30\%程度低いため, 電流駆動効率を重視する概念設計段階での ITER で は IC システムは副案と言う位置付けになっている ${ }^{18)}$. しかし最近, 速波による電子加熱（ランダウ減衰 (ELD）又は走行時間磁気ポンプ(TTMP)）は JET-2M ${ }^{19)}$ ，JET ${ }^{15)}$ ，JIPP-T II U ${ }^{20)}$ ，JT-60 21) で観測され， HT- $2^{20)}$ では速波電流駆動を明白に示す実験データが得られている。 また，近い将来 DIII-D, JET で本格的 な速波の電流駆動の実験が行われる予定である，速波の電流駆動の実験には高い電子温度（6-10keV 以上） が必要とされるため, これら大型トカマクで速波電流駆動の実証が期待出来る. また IC 加熱は NBの透過 が困難となる高電子密度プラズマ $\left(<n_{\mathrm{e}}>\geq 1.5 \times 10^{20} \mathrm{~m}^{-3}\right)$ でも中心部のイオン加熱が可能であるという長 
所を有することから，IC システムを主案に加えて主案を加熱に対しても，より最適化すべきだという意見 も専門家の間では強い．従って副案と言う位置づけにもかかわらず，IC システムの設計検討も熱心に行わ れた。ここでは ITER の概念設計段階で行われた IC システムの物理検討及び工学検討の内容, 即ち電流駆 動・加熱に適した周波数範囲の選択, アンテナの概念, システムの概要, R\&D の必要項目などを紹介する.

\section{2 周波数範囲の選択}

速波と電子との相互作用（ELD と TTMP）に基づく電流駆動は理論的に高い駆動効率が期待できる22）。し かし実際面で駆動効率を下げる要因としてアルファ粒子や燃料イオンのサイクロトロン共鳴によるパワー吸 収，捕捉電子の効果，或いはアンテナ用のポートの制約（波動スペクトルの最適化に影響する）などが挙げ られる，従ってアンテナの配置が炉構造と整合が取れ，且つ電流駆動効率を理想的に高く出来る解を見つけ る必要がある。このため電流駆動に適した周波数及びアンテナの概念の検討に多くの努力が払われた，その 結果15-80MHz の周波数範囲が選ばれた，表5-1にこの周波数範囲で期待される機能を示す，最も電流駆動効 率が高いのはイオンのサイクロトロン共鳴層をプラズマ断面から完全に外せるまで周波数を下げた場合であ り，現 ITER の装置パラメータでは $17 \mathrm{MHz}$ となる。しかし電流駆動効率を高くするためにはループアンテナ を多数（少なくとも16本程度）トロイダル方向に並べる必要があるが，周波数が低くなるとアンテナの間隔 を大きくする必要があり $\left(N_{/ /}=2\right.$ で波長 $\left.=8.8 \mathrm{~m}\right), 1$ つの水平ポートの開口巾 $(1.1 \mathrm{~m})$ にはアンテナ列が収 まらなくなる。このため次節で述べるブランケット内アンテナの概念を採用した。これによりポートの制約 を受けることなく連続的にアンテナを配置することが出来る。電流駆動効率 $\gamma \cdot\left(10^{20} \mathrm{Am}^{-2} \mathrm{~W}^{-1}\right)$ の計算值は 約0.3である. $2 \omega_{\mathrm{cT}}$ 近傍の周辺数 $(\sim 55 \mathrm{MHz})$ が次に電流駆動に適している. 三重水素へのパワー吸収 (20-30\%) がある分, $17 \mathrm{MHz}$ の場合より電流駆動効率は悪くなる（ $\gamma=0.2-0.25)$. 加熱のシナリオに対し ては重水素の基本波共鳴加熱 $(33 \mathrm{MHz}$,

高濃度少数イオン加熱), 三重水素の第 2 次共鳴加熱 $(44 \mathrm{MHz})$, 重水素の第 2 次 共鳴加熱（66MHz）までを含む．全てプ ラズマ中心部のイオン加熱が可能である ほか，表5-1に示すように多彩な機能を 有する，水素（非反応）プラズマの加熱 は $\mathrm{He}^{4}$ の少数イオン第 2 次共鳴加熱を用 いる.

上記の周波数範囲を選ぶことにより， ITER で考えられている全ての運転モー ドに対応でき，且つプラズマ制御面に於
表5-1. ITER/IC 波電流駆動加熱のシナリオ

\begin{tabular}{|c|c|c|c|}
\hline 周波数 & IC 共鵬（軸上） & 吸 & 機 \\
\hline $17 \mathrm{MHz}$ & $\begin{array}{l}\text { 無 } L \\
\left(\omega<\omega_{\mathrm{CT}}\right)\end{array}$ & 電子(TTMP) & $\begin{array}{l}\text { 電流駆動 } \\
(\gamma \sim 0.3)\end{array}$ \\
\hline $33 \mathrm{MHz}$ & $\begin{array}{l}\omega_{\mathrm{CD}} \\
\omega_{\mathrm{cHe} 4}\end{array}$ & $\begin{array}{l}\mathrm{D}\left(n_{\mathrm{D}} / n_{\mathrm{T}}>0.2\right) \\
\mathrm{He}^{4}\end{array}$ & $\begin{array}{l}\text { 中心イオン加熱 } \\
\text { 自己点火アプローチ }\end{array}$ \\
\hline $44 \mathrm{MHz}$ & $\begin{array}{l}\omega_{\mathrm{cHe} 3} \\
2 \omega_{\mathrm{cT}} \\
\left(\omega>2 \omega_{\mathrm{cT}}\right)\end{array}$ & $\begin{array}{l}\mathrm{He}^{3} \\
\mathrm{~T}\end{array}$ & $\begin{array}{l}\text { 中心（イオン）加熱 } \\
\text { 燃焼制御 } \\
\text { 鋸菌状振動安定化 } \\
\text { D-He }{ }^{3} \text { 燃焼 }\end{array}$ \\
\hline $54 \mathrm{MHz}$ & 無し & $\begin{array}{l}\text { 電子 (TTMP) } \\
\text { 一単一パス昅収大 } \\
T\end{array}$ & $\begin{array}{l}\text { 電流駆動 } \\
(\gamma=0.2 \sim 0.25)\end{array}$ \\
\hline $66 \mathrm{MHz}$ & $\begin{array}{l}\omega_{\mathrm{cH}} \\
2 \omega_{\mathrm{cD}} \\
2 \omega_{\mathrm{cHe} 4}\end{array}$ & $\begin{array}{l}\mathrm{H} \\
\mathrm{D} \\
\mathrm{He}^{4}\end{array}$ & $\begin{array}{l}\text { 中心（イオン）加熱 } \\
\text { 燃焼制御 } \\
\text { 鋸歯状振動安定化 } \\
\text { 水素プラズマの加熱 }\end{array}$ \\
\hline
\end{tabular}


ても多彩な機能を有することが分かる。しかも 1 つのシステムでこの周波数範囲をカバーすることができる.

\section{3 アンテナ概念}

図5-1に ITER のブランケット内 IC アンテナの概念図を示す. ITER の外側ブランケットは 1 つのトロイ ダルセクション $(1 / 16)$ 当たり 3 分割構造となっている. 但し中央部のブランケットは水平ポートがあるた め上下に分割されている。 アンテナは 1 つのトロイダルセクション当たり計 6 本, 即ち水平ポート内に 2 本, 左右のブランケット内に 2 本づつ等間隔にトーラス赤道面上方に設置する. 各アンテナボックスの寸法 は幅 $0.55 \mathrm{~m}$, 高さ $1.25 \mathrm{~m}$, 奥行き $0.4 \mathrm{~m}$, アンテテナの内部導体（current strap）の長さは約 $1 \mathrm{~m}$, 幅は $0.25 \mathrm{~m}$ で ある.アンテナの総本数は必要とするパワーで決まり, 主電流駆動装置を想定する時は総出力 $130 \mathrm{MW}$ でアン テナ本数は 42 本 52 本 (7トロイダルセクション及びブランケットセクターを必要数使用), NB の補足シス テムと考える時は総出力50-60MW でアンテナ本数は20本程度必要である（2トロイダルセクション及びブラ ンケットセクター 4 個程度使用)。ここでアンテナ 1 本当たりの放射パワーを2.5-3MW としている．ファラ ディシールド面での高周波電力密度は3.6-4.4MW / $\mathrm{m}^{2}$ であり, 現在の多くの ICRF 加熱装置の通常の值 (3-12MW / $\left.\mathrm{m}^{2}\right)$ に準ずるものである.

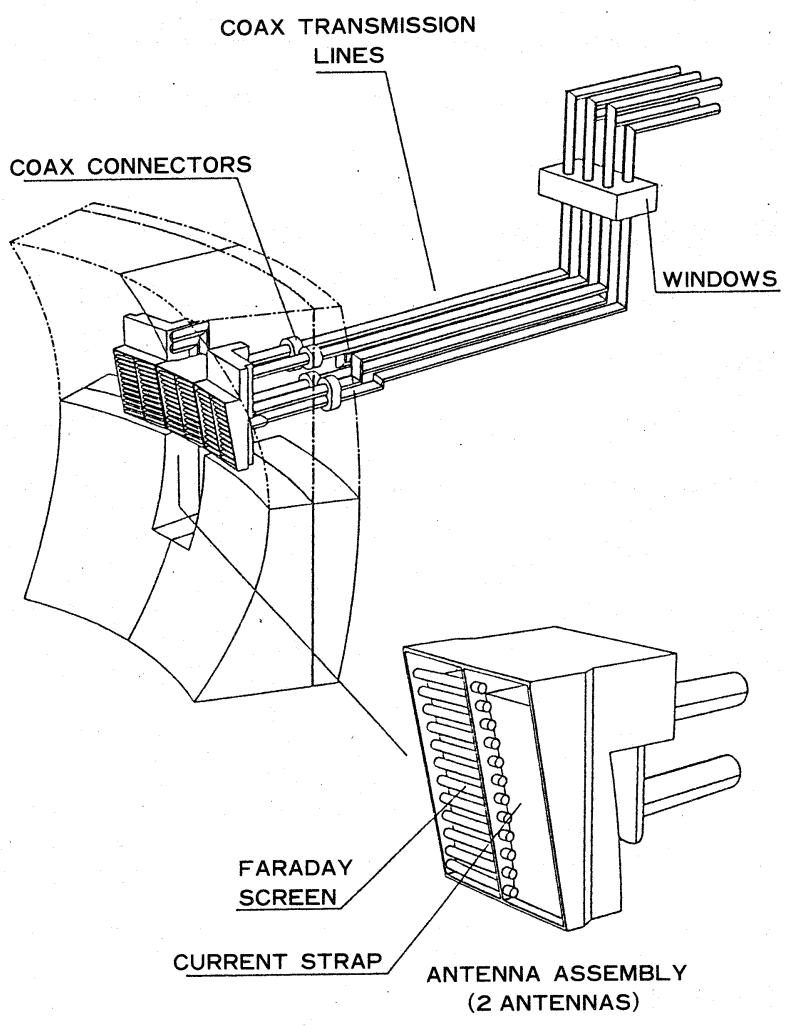

図5-1. ITER/IC 結合系の概念図 
図5-2に結合系全体の垂直断面，図5-3に水面断面を示す。アンテナ内部導体は同軸伝送管に接続され， ポートの上部に沿ってクライオスタットの外部に導かれる。七ラミックスの真空㝕は保守の容易なようにク ライオスタットの外部に設置する。問題はアンテナ内部導体と真空空の間の同軸管の内導体にセラミックス の支持が必要となることである，放射線照射（中性子と $\gamma$ 線）に伴う誘電損失の増加とディスラプション時 の電磁力に耐えなければならない，放射線照射に伴う誘電損失の増加に関するデー夕の取得は RF 装置共通 の重要課題である。同軸管内導体の支持をセラミックスで行う方法の代替案として導波管方式の伝送管（特 殊形状のリッジ導波管）を用いる結合系も提案された ${ }^{1)}$ 。この方法では周波数の下限は $50 \mathrm{MHz}$ 程度であり， 更に低周波領域（17MHz）に適用するには新しいアイデアが必要である。ファラディシールドは JT-60等で 実績を得た高周波損失を軽減できる単層オープン型23)であり, インコネル製の冷却パイプで構成される. プラズマに面する側は低Z材のタイルで保護する。グラファイトでは高周波損失が過大となるためにベリリ ウムなどの導電率の高い材料を用いる必要がある。

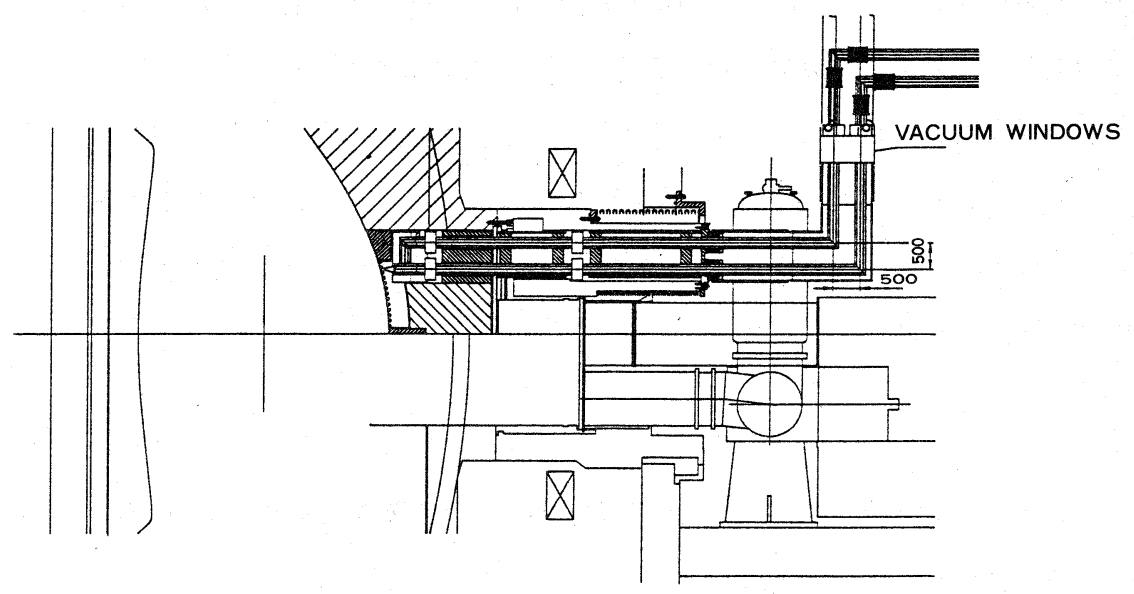

図5-2. ITER/IC 結合系の垂直断面

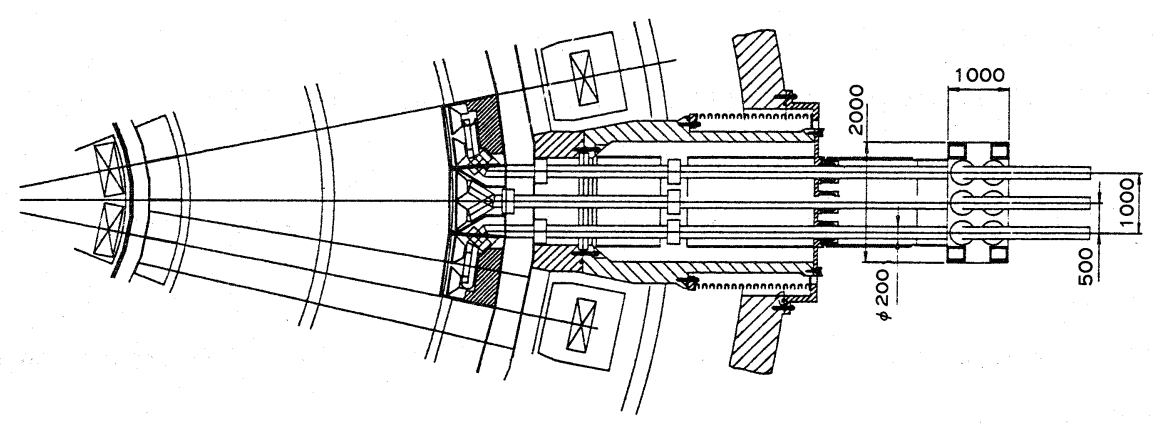

図5-3，ITER/IC 結合系の水平断面 
工学設計段階（EDA）ではアンテナ内部導体の支持方式, ファラディシールドの遠隔保守を含めて結合系 の信頼性の高い構造の確立が重要課題となろう．またアンテナの放射スペクトルの最適化とアンテナのイン ピーダンス整合の容易さの両立（例えばアンテナ間のしきり板の最適化）も重要である.

\section{4 システムの概要}

ITER の IC システムは現世代の核融合実験装置の IC システムに比べると大規模な設備となるが, 1 高 周波増幅器列に対して1アンテナが対応しており, その構成は現在の IC システムとほとんど同じで単純で ある. 即ち増幅器列ーアンテナの系統は大電力増幅器列, 同軸伝送管, インピーダンス整合器, 真空空, 真 空部伝送管, アンテナからなる。全体のシステムは必要とするパワーに応じてこの単位系統の数で決まる. 大電力増幅器の出力は $3 \mathrm{MW}, \mathrm{CW}$ を想定する。現在のシステムでは $2 \mathrm{MW}, 20 \mathrm{~s}$ が最大であるが, $3 \mathrm{MW}$ の四 極管の開発はほぼ完了しており十分に実現可能である。キャビティは $15 \mathrm{MHz}$ から $80 \mathrm{MHz}$ まで同調可能であ り, 且つ運転中に加熱用の周波数と電流駆動用の周波数との切替えが高速に行えるものにする必要がある. また電流駆動のために各アンテナ間の位相制御を励振増幅部で行う，増幅器から炉室内の整合器までのパワ 一伝送には直径10インチ程度の同軸管を用いる。パワー損失は伝送長 $100 \mathrm{~m}$ に対して約 $2 \%$ と極めて小さ い. 整合器には周波数範囲が広いためラインストレッチャーとスタブチューナーの組み合わせが適してい る. 真空部伝送管, アンテナは共に水冷却が必要であり, 真空部伝送管には高周波入射時に高真空を維持す るために真空排気ポンプ $(\sim 100 \mathrm{l} / \mathrm{s})$ が必要である. システム総合効率は標準的な設計で約 $53 \%$, 野心的な 設計では約 $64 \%$ 見込まれる。

\section{5 R\&D}

IC システムに対する EDA 期間中の必要 R\&D 項目はアンテナ要素に関するもののみと考えられており, その主な内容は以下の通りである。

（1）電流駆動アンテナシステムの試験；モデルアンテナを製作し，テストスタンド及び現存のトカマク 装置に装着し，耐電力及び位相制御，方向性の確認試験を行う。信頼性の高いアンテナの開発のため には実際のトカマク環境下での試験が不可欠である。

（2）七ラミックスの放射線照射試験；誘電損失及び絶縁破壊電圧の中性子束及びフルーエンス依存性を 測定する.

（3）導波管の開発 ; 周波数範囲 $80 \mathrm{MHz}$ 以下で使用可能でセラミックスを用いない導波管方式の真空部伝 送管の開発を行う。

なお15-80MHz で高速同調可能な大電力増幅器の開発も重要であるが, これまでの実績から建設期間中に行 うことで対応出来ると考えている。 
6. 結

概念設計活動ではこれまで述べてきたように概念設計と並行して，CD\&H システムを製作するに必要な R\&D 項目についての計画を明らかにした。これから開始される工学設計活動では設計の詳細化を計ると同 時に各システムの R\&D を進めていくことが肝要である. 最後に, 電流駆動・加熱の概念設計に原研をはじ め, 大学, 国立研究機関, 並びに産業界から多くの方々に参加して戴き, 多くの成果を上げることができた ことをここに深く感謝いたします。

\section{参考文献}

1) V. Parail et al. : ITER : Current Drive and Heating System, IAEA/ITER/DS/No. 32, IAEA, Vienna (1991).

2) S. Yamamoto et al. : Proc. 11th Int. Conf. on Plasma Physics and Controlled Nuclear Fusion Research, IAEA$\mathrm{CN}-47 / \mathrm{H}-\mathrm{I}-3$, Kyoto (1986).

3) Neutral Beam Conceptual Design Proposals for ITER, ITER-IL-HD-4-0-33 (1990).

4) Neutral Beam System Interim Report, ITER-IL-HD-4-9-14 (1989).

5) M. Mizuno et al. : Proc. 13th Symp. on Fusion Engineering, Knoxville (1989) 574.

6) K. Maki et al. : Japan Atomic Energy Research Institute Report, JAERI-M91-046 (1991).

7) Y. Okumura et al. : Proc. 16th Symp. on Fusion Thecnology, London (1990) R-07.

8) M. Goniche et al. : CEA-DRCF, Rpt., (Dec. 1989).

9) K. Shibanuma et al. : Proc. 16th Symp. on Fusion Thecnology, London (1990).

10) R. Andreani et al. : Proc. 11th Symp. of Fusion Eng., Austin (1985) p. 1324

11) I. I. Antakov, V.E. Myazsnikov et al. : International Workshop on Strong Microwaves in Plasmas, Suzdal, USSR (September 1990).

12) K. Sakamoto et al. : "Electron Cyclotron Wave System for ITER Common Conceptual Design" ITER-IL-HD6-0-27 (1990).

13) M. Tsuneoka et al. : "The Design of RF Power Supply using DC-DC Convertor" , Proc. 13th Symp. on Fusion Engineering, Knoxville, Tennessee, USA (1989).

14) The JET Team (presented by D. J. Campbell): "Sawteeth and their Stabilization in JET", Proc. 13th Int. Conf. on Plasma Physics and Controlled Nuclear Fusion Research, Washington (1990), IAEA-CN-53/A-6-3.

15) The JET Team (presented by D.F.H. Start): “ICRF Heating in Reactor Grade Plasmas" , Proc. 13th Int. Conf. on Plasma Physics and Controlled Nuclear Fusion Research, Washington (1990), IAEA-CN-53/E-2-1-1.

16) D. A. D'Ippolito et al. : "ICRF Impurity and Antenna Studies" , Proc. 13th Int. Conf. on Plasma Physics and Controlled Nuclear Fusion Research, Washington (1990), IAEA-CN-53/E-3-1.

17) M. Brambilla et al. : "Theoretical and Experimental Investigation of a Mechanism for Impurity Production by ICRF Fields" , Proc. 13th Int. Conf. on Plasma Physics and Controlled Nuclear Fusion Research, Washington (1990), IAEA-CN-53/E-2-5.

18) W. M. Nevins et al. : "ITER Current Drive and Heating Physics" , Proc. 13th Int. Conf. on Plasma Physics and Controlled Nuclear Fusion Research, Washington (1990), IAEA-CN-53/F-3-4.

19) Y. Uesugi et al. : Nuclear Fusion 30 (1990) 831.

20) T. Watari et al. : "Application of Intermediate Frequency Range Fast Wave to JIPP T-IIU and HT-2 Plasma", Proc. 13th Conf. on Plasma Physics and Controlled Nuclear Fusion Research, Washington (1990), IAEA-CN-53/ E-3-3.

21) JT-60 Team : Japan Atomic Research Institute Report, JAERI-M 90-066 (1990) 115.

22) J. G. Cordey : Plasma Physics and Controlled Fusion 26 (1984) 123.

23) T. Nagashima et al. : Fusion Engineering and Design 5 (1987) 101. 